Omni-Akuatika, 12 (3): 79 - 87, 2016
ISSN: 1858-3873 print / 2476-9347 online
Research Article

\title{
Aspek Biologi lkan Layang (Decapterus russelli) di Perairan Latuhalat, Kecamatan Nusaniwe, Pulau Ambon
}

\author{
Ong T.S. Ongkers ${ }^{1}$, Jesaja A. Pattikawa ${ }^{1 \star}$, Frederick Rijoly ${ }^{1}$ \\ 'Jurusan Manajemen Sumberdaya Perairan-Fakultas Perikanan dan IImu Kelautan, Universitas Pattimura, Poka- \\ Ambon \\ ${ }^{*}$ Corresponding author: boypattikawa@yahoo.com
}

\begin{abstract}
This research was carried out in the waters of Latulahalat, Ambon Island from June to August 2016. The objectives of the research were to study some biological aspects namely sex ratio, gonad maturity level, size distribution and growth pattern of scad mackerel, Decaterus russelli. Fish samples were collected every month at fish landing from purse seine fishers. Sex ratios of scad mackerel in the area were equal i.e. 1:1 with the male dominated gonad maturity levels I and IV while female dominated gonad maturity levels II, III and V. In general, male fishes were smaller than female ones in term of length and weight. Scad mackerel in the area showed positive allometric growth except for male on August which showed isometric growth
\end{abstract}

Keywords: Decaterus russelli, sex ratio, .gonad maturity level, growth pattern

\section{Pendahuluan}

Propinsi Maluku sering dijuluki sebagai propinsi kepulauan karena memiliki wilayah laut yang luas yaitu sebesar $92,4 \%$ dari total wilayahnya (DKPP Maluku, 2014). Dengan perairan laut yang begitu luas maka tidaklah mengherankan apabila propinsi Maluku memiliki berbagai sumberdaya hayati laut. Salah satu sumberdaya hayati laut tersebut adalah ikan pelagis kecil yang sebahagian besar merupakan hasil tangkapan nelayan dengan jaring giob (purse seine).

Jenis-jenis ikan pelagis kecil yang mendominasi hasil tangkapan dan tertangkap sepanjang tahun sebahagian besarnya berasal dari genus Decapterus. Salah satu jenis dari genus ini adalah ikan layang (Decapterus russelli) yang selalu tertangkap sepanjang tahun oleh nelayan purse seine di perairan pulau Ambon dan sekitarnya.

Dalam upaya pengelolaan sumberdaya perikanan, terutama sumberdaya ikan pelagis kecil yang memiliki nilai ekonomis maka diperlukan informasi yang up to date tentang sumberdaya tersebut. Informasi-informasi seperti potensi dan tingkat pemanfaatan, dinamika populasi dan aspek biologi sangatlah diperlukan sehingga sumberdaya ikan pelagis kecil dapat dikelola dengan baik dan dimanfaatkan secara berkelanjutan.

Penelitian ini dilakukan untuk mengkaji aspek biologi yang meliputi rasio kelamin, tingkat kematangan gonad, sebaran ukuran dan pola pertumbuhan ikan layang $(D$. russelli) di perairan Latuhalat. Hasil penelitian ini diharapkan dapat menambah dan memperkaya informasi yang ada sehingga dapat digunakan dalam pengelolaan ikan layang khususnya di perairan pulau Ambon maupun secara umum di perairan Maluku.

\section{Metodologi Penelitian}

\section{Lokasi penelitian}

Penelitian ini dilakukan di wilayah perairan Latuhalat, Kecamatan Nusaniwe, pada bulan Juni hingga Agustus 2016 dengan menggunakan alat tangkap jaring giob (purse seine).

\section{Pengambilan data}

Pengambilan sampel ikan layang dilakukan secara langsung dari hasil tangkapan nelayan purse seine setiap bulan selama tiga bulan. Sampel yang diperoleh dipisahkan menurut jenis kelaminnya kemudian diukur 
panjang cagaknya dan ditimbang beratnya. Selanjutnya dari sampel ikan yang didapat setiap bulan diambil masing-masing 10 ekor jantan dan 10 ekor betina untuk diamati tingkat kematangan gonadnya.

Pengamatan untuk menentukan jenis kelamin dilakukan dengan cara memencet perut ikan secara perlahan-lahan dan kemudian mengamati cairan yang keluar. Ikan berkelamin jantan ditandai dengan keluarnya cairan berwarna putih, sedangkan kelamin ketina cairannya berwarna orange.

Tingkat kematangan gonad (TKG) dilakukan secara morfologi dengan mengamati warna, bentuk dan ukuran gonad menurut Cassie dalam Effendie (1997) (Tabel 1).

Tabel 1. Tingkat kematangan gonad ikan

\begin{tabular}{|c|c|c|}
\hline $\begin{array}{c}\text { Tingkat } \\
\text { Kematangan }\end{array}$ & Betina & Jantan \\
\hline 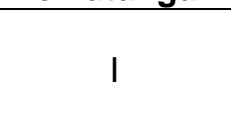 & $\begin{array}{l}\text { Ovari seperti benang, panjang } \\
\text { sampai kedepan rongga tubuh. } \\
\text { Warna jernih. Permukaan licin. }\end{array}$ & $\begin{array}{l}\text { Testes seperti benang, lebih pendek } \\
\text { (terbatas) dan terlihat ujung-ujungnya di } \\
\text { rongga tubuh. Warna jernih. }\end{array}$ \\
\hline II & $\begin{array}{l}\text { Ukuran ovary lebih besar. } \\
\text { Pewarnaan lebih gelap kekuning- } \\
\text { kuningan. Telur belum terlihat jelas } \\
\text { dengan mata. }\end{array}$ & $\begin{array}{l}\text { Ukuran testes lebih besar. Pewarnaan } \\
\text { putih seperti susu. Bentuk lebih jelas } \\
\text { pada tingkat I. }\end{array}$ \\
\hline III & $\begin{array}{l}\text { Ovary berwarna kuning, secara } \\
\text { morfologi telur mulai kelihatan } \\
\text { butirnya dengan mata. }\end{array}$ & $\begin{array}{l}\text { Permukaan testes tampak bergerigi. } \\
\text { Warna makin putih, testes makin besar. } \\
\text { Dalam keadaan awet mudah putus. }\end{array}$ \\
\hline IV & $\begin{array}{l}\text { Ovary makin besar, telur berwarna } \\
\text { kuning, mudah dipisahkan. Butir } \\
\text { minyak tidak tampak, mengisi } 1 / 2-2 / 3 \\
\text { rongqa perut, usus terdesak. }\end{array}$ & $\begin{array}{l}\text { Seperti pada tingkat III tampak lebih } \\
\text { jelas. Testes semakin pejal. }\end{array}$ \\
\hline V & $\begin{array}{l}\text { Ovary berkerut, dinding tebal, butir } \\
\text { telur sisa terdapat didekat } \\
\text { pelepasannya. }\end{array}$ & $\begin{array}{l}\text { Testes bagian belakang kempis dan di } \\
\text { bagian dekat pelepasan masih berisi. }\end{array}$ \\
\hline
\end{tabular}

\section{Analisa data}

\section{Rasio kelamin}

Rasio kelamin ditentukan dengan membandingkan jumlah ikan layang jantan dan ikan layang betina yang berasal dari sampel. Untuk menguji apakah ada penyimpangan dari rasio ideal 1 : 1 antara jantan dan betina, digunakan uji chi-square (Fowler and Cohen, 1992):

$$
x^{2}=\sum \frac{(\mathrm{O}-\mathrm{E})^{2}}{\mathrm{E}}
$$

Keterangan :

$\mathrm{O}=$ Frekuensi jantan dan betina dalam sampel

$\mathrm{E}=$ Frekuensi jantan dan betina secara teoritis Kriteria Penilaian :

$$
\begin{aligned}
& X^{2}{ }_{\text {nitung }}<X^{2} \text { tabel maka rasio }=1: 1 \\
& X^{2}{ }_{\text {hitung }}>X^{2}{ }_{\text {tabel }} \text { maka rasio } \neq 1: 1
\end{aligned}
$$

\section{Pola pertumbuhan}

Pola pertumbuhan ikan ditentukan dengan melihat hubungan antara panjang dan berat ikan. Analisa hubungan panjang berat dilakukan dengan menggunakan persamaan berpangkat yang dikemukakan oleh Pauly (1984):

$$
\mathbf{W}=\mathbf{a} \mathbf{L}^{\mathbf{b}}
$$

Keterangan :

$$
\begin{aligned}
& W=\text { berat tubuh ikan (gram) } \\
& L=\text { Panjang tubuh ikan }(\mathrm{cm}) \\
& \mathrm{a} \text { dan } \mathrm{b}=\text { Konstanta }
\end{aligned}
$$

Untuk menguji nilai $b$, apakah $b=3$ atau $b \neq 3$ digunakant t-student test menurut Pauly (1984): 


$$
t=\left(\frac{s d(x)}{s d(y)}\right)\left(\frac{|b-3|}{\sqrt{1-r^{2}}}\right)(\sqrt{n-2})
$$

Keterangan :

$\mathrm{Sd}(\mathrm{x})=$ Standard Deviasi untuk nilai $\log \mathrm{L}$

$\mathrm{Sd}(\mathrm{y})=$ Standard Deviasi untuk nilai log $\mathrm{W}$

$\mathrm{b} \quad=$ slope yang didapat pada hubungan panjang-berat

$\mathrm{n} \quad=$ Jumlah sampel

$r^{2} \quad=$ Koefisien determinasi

Kriteria penilaian :

bila $t_{\text {hitung }}<t$ tabel maka $b=3$, pertumbuhannya isometrik

bila $t_{\text {nitung }}>t$ tabel maka $b \neq 3$, pertumbuhannya alometrik

Nilai b pada tingkat kepercyaan 95\% $(p=0,05)$ ditentukan dengan persamaan Sparre and Venema (1992) yaitu :

$$
b \pm t \times s b
$$

Keterangan :

$t=t$ tabel $(p=0,05 ; n-2)$

$s b=$ Simpangan baku $b$.

\section{Hasil dan Pembahasan}

\section{Rasio kelamin}

Selama penelitian yang dilakukan pada bulan Juni - Agustus didapatkan 443 individu ikan layang yang terdiri dari 220 individu jantan dan 223 individu betina (Tabel 2). Ikan betina umumnya lebih banyak dibandingkan dengan ikan jantan untuk setiap bulan pengamatan, kecuali di bulan Agustus. Walaupun demikian, hasil uji chi-square yang terdapat pada Tabel 2 memperlihatkan bahwa nilai $x^{2}$ hitung $<x^{2}$ tabel baik untuk setiap bulan pengamatan maupun secara keseluruhan. Hasil uji ini berarti rasio antara ikan berkelamin jantan dan betina berada dalam kondisi seimbang atau sama yaitu $1: 1$.

Perbandingan jumlah ikan layang jantan dan betina yang sama atau memiliki rasio kelamin 1: 1 juga ditemukan oleh beberapa peneliti lain seperti Sumadhiharga (1994) di Teluk Ambon dan Genisa (1998) di Perairan Tegal dan di Selat Makasar.

Menurut Sulistiono dkk (2009), rasio kelamin 1:1 merupakan kondisi ideal karena kedua jenis kelamin sama-sama aktif sehingga memiliki peluang yang sama untuk tertangkap. Disamping itu, rasio kelamin yang sama ideal untuk reproduksi karena memungkinkan satu ikan jantan akan membuahi satu ikan betina.

Penyimpangan rasio kelamin dari pola 1:1 dapat timbul dari berbagai faktor yang mencakup perbedaan distribusi, aktivitas dan gerakan ikan (Turkmen et al. 2002); pergantian dan variasi seksual jantan dan betina dalam masa pertumbuhan, mortalitas dan lama hidup (Sadovy 1996 dalam Simanjuntak 2007).

Tabel 2. Rasio kelamin ikan layang selama periode penelitian

\begin{tabular}{cccccc}
\hline Periode & $\begin{array}{c}\text { Jantan } \\
\text { (ekor) }\end{array}$ & $\begin{array}{c}\text { Betina } \\
\text { (ekor) }\end{array}$ & $\begin{array}{c}\text { Rasio } \\
\text { jantan : betina }\end{array}$ & $\begin{array}{c}\mathbf{X} 2 \\
\text { hitung dan } \mathbf{2} \text { tabel } \\
(\mathbf{P}=\mathbf{0 . 0 5} \text {;db=1) }\end{array}$ & $\begin{array}{c}\text { Jumlah } \\
\text { (ekor) }\end{array}$ \\
\hline $\begin{array}{c}\text { Juni } \\
\text { Juli }\end{array}$ & 62 & 69 & $0.90: 1.00$ & $0.37<3.84$ & 131 \\
Agustus & 69 & 70 & $0.99: 1.00$ & $0.01<3.84$ & 139 \\
\hline Total & 89 & 84 & $1.00: 0.94$ & $0.14<3.84$ & 173 \\
\hline
\end{tabular}


Tabel 3. Tingkat kematangan gonad ikan layang selama periode penelitian

\begin{tabular}{ccccccccccc}
\hline \multirow{2}{*}{ TKG } & \multicolumn{2}{c}{ Juni } & \multicolumn{2}{c}{ Juli } & \multicolumn{2}{c}{ Agustus } & \multicolumn{2}{c}{ Total (\%) } \\
\cline { 2 - 10 } I & Jantan & Betina & Jantan & Betina & Jantan & Betina & Jantan & Betina \\
II & 3 & 0 & 6 & 1 & 5 & 0 & 14 & $(46.7)$ & 1 & $(3.4)$ \\
III & 3 & 5 & 1 & 6 & 0 & 1 & 4 & $(13.3)$ & $12(40.0)$ \\
IV & 2 & 3 & 1 & 2 & 0 & 4 & 3 & $(10.0)$ & $9(30.0)$ \\
V & 2 & 2 & 2 & 1 & 5 & 1 & 9 & $(30.0)$ & $4(13.3)$ \\
\hline Jumlah & 0 & 0 & 0 & 0 & 0 & 4 & 0 & $(0.0)$ & $4(13.3)$ \\
\hline
\end{tabular}

\section{Tingkat kematangan gonad}

Tingkat kematangan ikan layang selama periode penelitian dapat dilihat pada Tabel 3 . Secara keseluruhan, ikan layang jantan mendominasi TKG I dan TKG IV, sedangkan ikan betina mendominasi TKG II, TKG III dan TKG V. Berdasarkan periode penelitian, ikan jantan di bulan Agustus memiliki TKG yang khas karena hanya memiliki TKG I dan TKG IV. Effendie (1997) menyatakan bahwa pengetahuan tentang tingkat kematangan gonad sangat diperlukan dalam biologi perikanan karena dapat digunakan untuk mengetahui perbandingan ikan yang melakukan reproduksi dan yang tidak bereproduksi pada suatu perariran. Selanjutnya dikatakan bahwa ikan pada perairan tropis gonadnya akan matang lebih cepat dan umumnya memijah sepanjang tahun sehingga dengan mengetahui persentase ikan-ikan yang matang gonad maka dapatlah waktu pemijahannya. Puncak pemijahan dapat diprediksi dengan melihat persentase yang tinggi dari tingkat kematangan gonad yang besar.

\section{Sebaran ukuran}

Sebaran ukuran ikan layang selama periode penelitian dapat dilihat pada Tabel 4 . Ikan layang jantan memiliki kisaran ukuran panjang 7.5 - $23.5 \mathrm{~cm}$ dengan kisaran berat 7.4 - 207.8 gram sedangkan kisaran panjang ikan layang betina adalah $9.4-28.6 \mathrm{~cm}$ dan 7.5 244.6 gram untuk berat. Ukuran panjang ratarata terbesar dimiliki oleh ikan betina layang di bulan Juni yaitu $17.51 \mathrm{~cm}(\mathrm{SE}=0.53)$ dengan berat rata-rata 97.66 gram $(\mathrm{SE}=8.30)$, sedangkan ukuran rata-rata terkecil diwakili oleh ikan jantan di bulan Juli dengan panjang rata-rata $14.75 \mathrm{~cm}((\mathrm{SE}=0.40)$ dan berat 49.86 gram (SE=6.31). Kisaran ukuran panjang ikan layang yang didapatkan dalam penelitian ini hampir sama dengan kisaran ukuran ikan layang di Teluk Likupang, Sulawesi Utara yaitu 8.4 - $25.2 \mathrm{~cm}$ (Manik, 2009). Ukuran panjang rata-rata yang didapatkan dalam penelitian ini tidak berbeda jauh dengan ukuran rata-rata ikan layang di Laut Jawa yaitu $15.53 \mathrm{~cm}$ (Widodo,1988).

Menurut Widodo (1988), ikan layang di Laut Jawa matang pertama kali pada ukuran $13.9 \mathrm{~cm}$ dengan ukuran layak tangkap pertama kali adalah $14.8 \mathrm{~cm}$. Selanjutnya Prihatini (2006), menyatakan bahwa ikan layang berukuran $14.0 \mathrm{~cm}$ sudah dianggap matang pertama kali karena telah mencapai TKG III. Berdasarkan pernyataan ini dan ukuran ratarata pada Tabel 4 serta Gambar 1, maka dapat dikatakan bahwa sebahagian besar ikan layang yang tertangkap dalam penelitian ini telah dewasa dan layak tangkap. 
Tabel 4. Statistik deskriptif ikan layang selama periode penelitian

\begin{tabular}{|c|c|c|c|c|c|c|c|c|c|}
\hline \multirow[t]{2}{*}{ Periode } & \multirow[b]{2}{*}{$\mathbf{n}$} & \multicolumn{4}{|c|}{ Panjang (cm) } & \multicolumn{4}{|c|}{ Berat (g) } \\
\hline & & Min & Max & Rata-rata & SE & Min & Max & Rata-rata & SE \\
\hline Juni & & & & & & & & & \\
\hline Jantan & 62 & 10.2 & 23.0 & 16.3 & 0.53 & 7.4 & 207.8 & 76.70 & 8.53 \\
\hline Betina & 69 & 10.0 & 27.0 & 17.51 & 0.53 & 8.1 & 244.6 & 97.66 & 8.30 \\
\hline $\begin{array}{c}\text { Gabungan } \\
\text { Juli }\end{array}$ & 131 & 10.0 & 27.0 & 16.86 & 0.38 & 7.4 & 244.6 & 87.74 & 6.00 \\
\hline Jantan & 69 & 9.4 & 23.5 & 14.75 & 0.40 & 7.4 & 180.0 & 49.86 & 6.31 \\
\hline Betina & 70 & 9.5 & 28.6 & 15.66 & 0.44 & 8.1 & 186.0 & 58.23 & 6.59 \\
\hline $\begin{array}{l}\text { Gabungan } \\
\text { Agustus }\end{array}$ & 139 & 9.4 & 28.6 & 15.21 & 0.30 & 7.4 & 186.0 & 54.08 & 4.57 \\
\hline Jantan & 89 & 7.5 & 23.2 & 14.88 & 0.41 & 7.4 & 207.8 & 57.05 & 5.95 \\
\hline Betina & 84 & 9.4 & 23.0 & 15.78 & 0.43 & 7.5 & 187.4 & 68.48 & 6.65 \\
\hline $\begin{array}{c}\text { Gabungan } \\
\text { Total }\end{array}$ & 173 & 7.5 & 23.2 & 15.21 & 0.30 & 7.4 & 207.8 & 61.63 & 4.45 \\
\hline Jantan & 220 & 7.5 & 23.5 & 15.19 & 0.26 & 7.4 & 207.8 & 59.65 & 3.99 \\
\hline Betina & 223 & 9.4 & 28.6 & 16.28 & 0.27 & 7.5 & 244.6 & 73.54 & 4.27 \\
\hline Gabungan & 443 & 7.5 & 28.6 & 15.74 & 0.19 & 7.4 & 244.6 & 66.64 & 2.94 \\
\hline
\end{tabular}
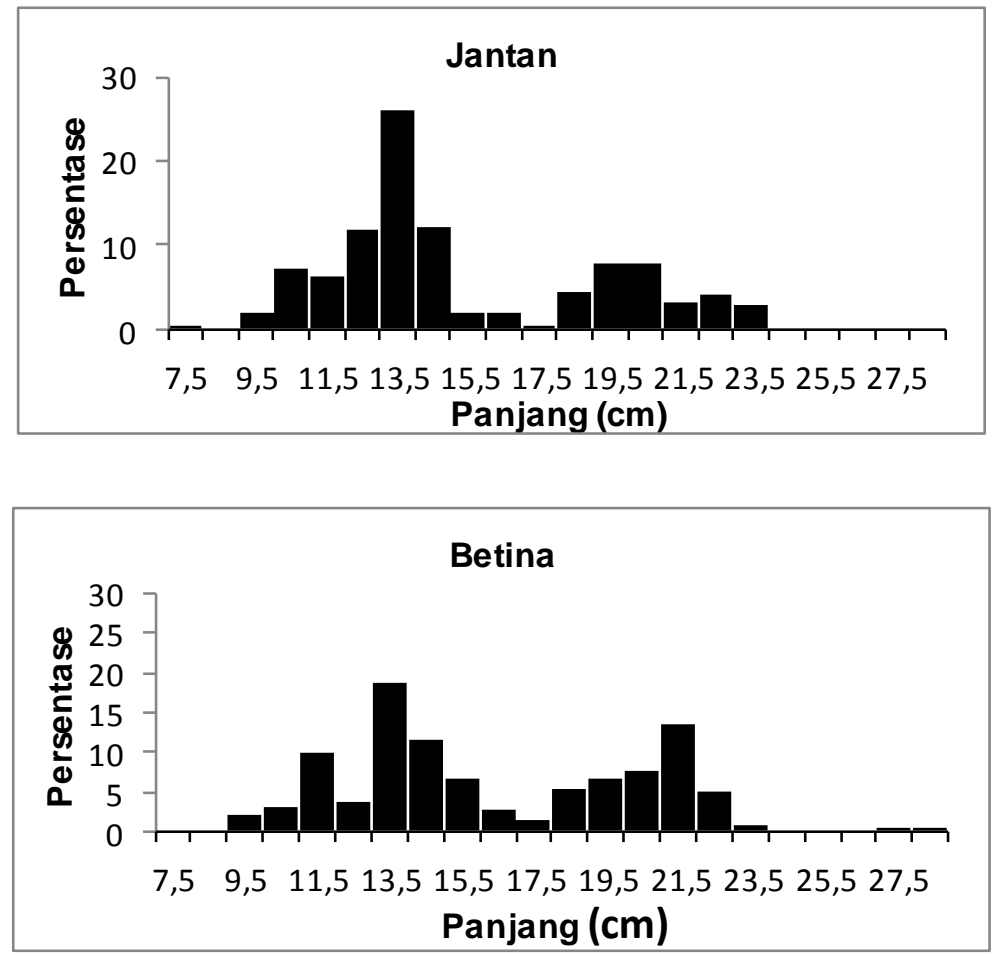


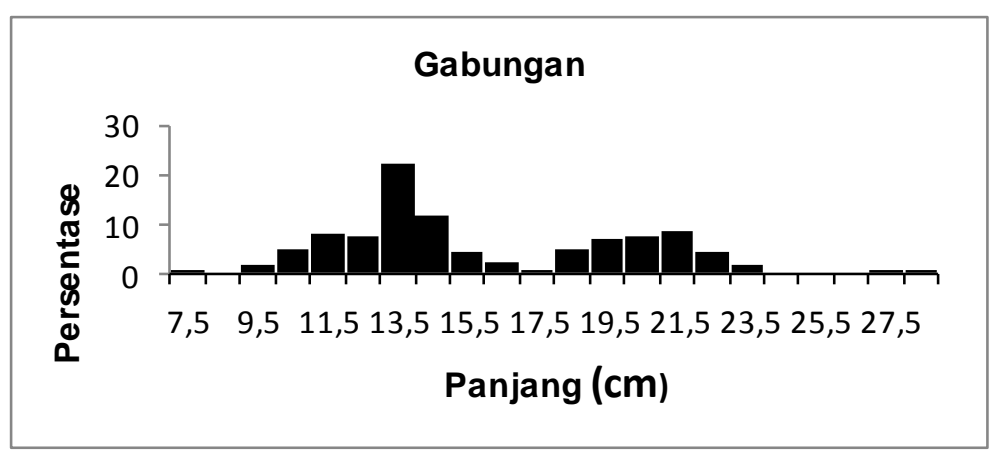

Gambar 1. Histogram frekuensi relatif panjang ikan layang total periode Juni - Agustus

\section{Pola pertumbuhan}

Hasil analisa hubungan panjang berat yang nantinya digunakan untuk menentukan pola pertumbuhan ikan layang dapat dilihat pada Tabel 5 dan Gambar 2. Pada Tabel 5 dapat dilihat bahwa nilai koefisien korelasi ( $r$ ) yang menggambarkan keeratan hubungan antara panjang dan berat berkisar dari 0.836 0.983 jauh lebih besar dari nilai koefisien korelasi tabel (critical value of $r$ ) pada tingkat kepercayaan $99 \%(P=0.01 ; d b=60)$ yaitu 0.295 sehingga dapat dikatakan bahwa ada hubungan yang sangat erat antara panjang dan berat. Dengan demikian maka persamaan panjang dan berat ini dapat digunakan dalam analisis selanjutnya.
Nilai b untuk setiap bulan pengamatan berkisar dari 3.123 - 4.152 dan nilai ini lebih besar dari 3 (Tabel 5, Gambar 3). Walaupun demikian, hasil uji dengan menggunakan $t$ Student test memperlihatkan bahwa ada hubungan panjang-berat yaitu pada bulan Agustus untuk ikan layang jantan yang memiliki nilai nilai $b$ yang tidak berbeda nyata dari $3(b=3) \quad\left(t_{\text {hitung }}=0.56<t_{\text {tabel }}=1.98\right)$. Hal ini diperkuat dengan melihat nilai selang $b$ pada tingkat kepercayaan 95\% (P=0,05) untuk ikan layang jantan pada bulan Agustus yaitu 2.686 3.560. Sparre and Venema (1992) menyatakan bahwa apabila selang nilai $\mathrm{b}$ pada tingkat kepercayaan $95 \%(P=0,05)$ mencakup nilai 3,0 maka nilai $b$ tersebut tidak berbeda nyata dari 3 $(b=3)$.

Tabel 5. Hasil uji t hubungan panjang-berat ikan layang selama periode penelitian

\begin{tabular}{|c|c|c|c|c|c|}
\hline Periode & $\mathbf{W}=\mathbf{a} \mathbf{L}^{\mathbf{b}}$ & $\mathbf{r}$ & t hitung & $t$ tabel & $\begin{array}{c}\text { Selang } \mathbf{b} \text { pada } \mathbf{p}= \\
0.05\end{array}$ \\
\hline \multicolumn{6}{|r|}{ 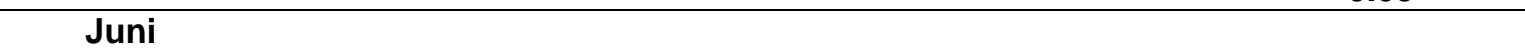 } \\
\hline Jantan & $W=0.0005 L^{4.152}$ & 0.983 & $2.67^{\star}$ & 2.00 & $3.594-4.350$ \\
\hline Betina & $W=0.0007 L^{4.019}$ & 0.983 & $11.11^{*}$ & 1.99 & $3.837-4.200$ \\
\hline $\begin{array}{c}\text { Gabungan } \\
\text { Juli }\end{array}$ & $W=0.0006 L^{4.0 / 5}$ & 0.983 & $16.22^{*}$ & 1.98 & $3.944-4.206$ \\
\hline Jantan & $W=0.0025 L^{3.555}$ & 0.883 & $2.41^{*}$ & 1.99 & $3.094-4.016$ \\
\hline Betina & $W=0.0012 L^{3.797}$ & 0.962 & $3.05^{*}$ & 1.99 & $3.537-4.057$ \\
\hline $\begin{array}{l}\text { Gabungan } \\
\text { Agustus }\end{array}$ & $W=0.0011 L^{3.671}$ & 0.926 & $5.23^{*}$ & 1.98 & $3.418-3.924$ \\
\hline Jantan & $W=0.0086 L^{3.123}$ & 0.836 & 0.56 & 1.98 & $2.686-3.560$ \\
\hline Betina & $W=0.0014 L^{3.186}$ & 0.948 & $5.61^{*}$ & 1.99 & $3.508-4.064$ \\
\hline $\begin{array}{r}\text { Gabungan } \\
\text { Total }\end{array}$ & $W=0.0038 L^{3.423}$ & 0.891 & $3.15^{\star}$ & 1.97 & $3.159-3.687$ \\
\hline Jantan & $W=0.0020 L^{3.630}$ & 0.915 & $3.63^{*}$ & 1.97 & $3.416-3.843$ \\
\hline Betina & $W=0.0010 L^{3.886}$ & 0.966 & $3.89^{*}$ & 1.97 & $3.750-4.027$ \\
\hline Gabungan & $W=0.0015 L^{3.757}$ & 0.942 & $3.76^{*}$ & 1.97 & $3.632-3.881$ \\
\hline
\end{tabular}

${ }^{*}$ berbeda nyata pada $\mathrm{p}=0.05$ 
Nilai $b$ pada hubungan panjang-berat dapat digunakan untuk melihat pola pertumbuhan ikan. Bila nilai $b=3$ maka dikatakan bahwa pertumbuhan ikan tersebut adalah isometrik yang berarti laju pertambahan ukuran panjang seimbang dengan pertambahan beratnya. Sebaliknya bila nilai $b \neq 3$ maka pertumbuhan ikan tersebut adalah alometrik yaitu alometrik negatif $(b<3)$ dimana pertumbuhan panjang lebih cepat dari pertumbuhan berat dan alometrik positif $(b>3)$ yang berarti pertumbuhan berat lebih cepat dari pertumbuhan panjang (Pauly, 1984).
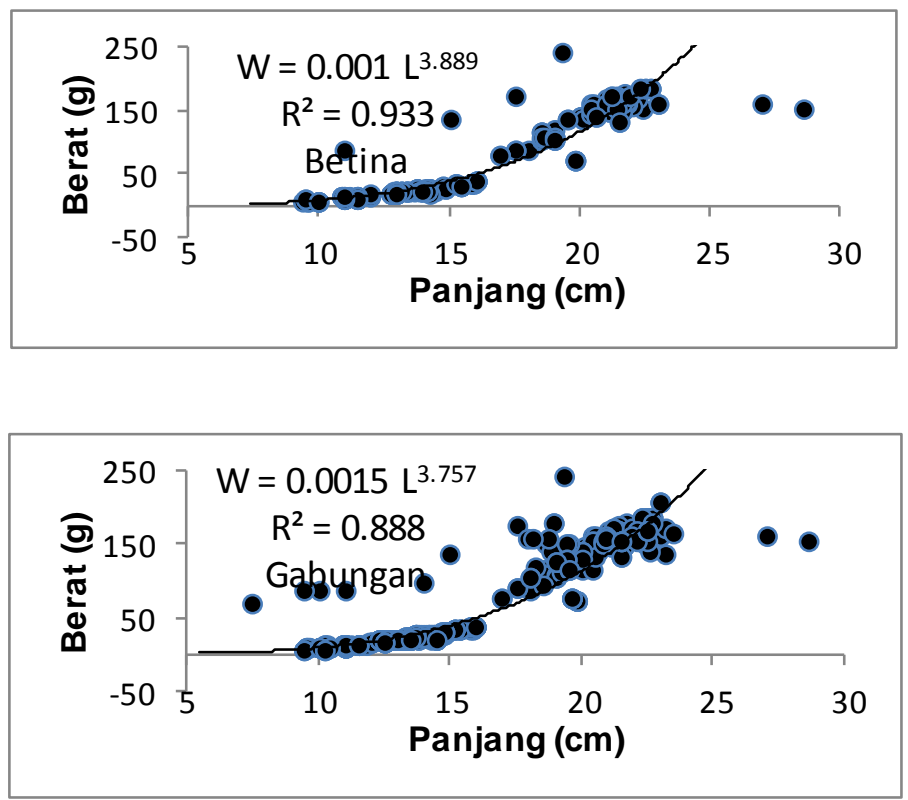

Gambar 2. Hubungan panjang berat ikan layang total periode Juni - Agustus

Dengan demikian dapat dikatakan bahwa hanya ikan layang jantan di bulan Agustus yang memiliki pola pertumbuhan isometrik $(b=3)$ yaitu pertambahan panjangnya seimbang dengan pertambahan berat. Sebaliknya ikan layang yang tertangkap di bulan lainnya memiliki pertumbuhan alometrik positif $(b>3)$ yang berarti pertambahan beratnya lebih cepat dari pertambahan panjang.
Aprilianty (2000) menyatakan bahwa ikan layang di perairan Teluk Sibolga, Sumatera Utara memiliki pola pertumbuhan isometrik. Pertumbuhan ikan layang yang bersifat isometrik juga didapatkan oleh Widodo (1988) di Laut Jawa. Sebaliknya Manik (2009) menyatakan bahwa pertumbuhan ikan layang yang isometrik hanya ditemui pada bulan Mei, sedangkan periode Juni hingga Oktober 
pertumbuhannya bersifat alometrik positif $(b$ > 3).

Bervariasinya nilai b mungkin dikarenakan adanya perbedaan tingkat kematangan gonad ikan sampel dan musim. Menurut Lecren (1951) dalam Merta (1993), nilai $b$ akan bervariasi menurut tempat, jenis kelamin serta tahapan pertumbuhan yang dicapai berbeda ( larva, juwana dan ikan matang gonad) oleh ikan-ikan contoh dan juga dapat disebabkan oleh kesuburan perairan.

Hubungan panjang berat penting dalam bidang perikanan karena selain digunakan untuk melihat pola pertumbuhan ikan yang dipelajari, hubungan ini dapat juga digunakan untuk menentukan faktor kondisi dan faktor konversi (Effendie, 1997). Dengan demikian apabila kita hanya memiliki salah satu variabel, misalnya hanya ukuran panjang maka nilai ini dapat dikonversi ke berat dan sebaliknya.

\section{Kesimpulan}

Berdasarkan hasil penelitian ikan layang selama periode Juni - Agustus 2016 di perairan Latuhalat dapatlah dibuat beberapa kesimpulan sebagai berikut:

1. Ikan layang yang tertangkap selama periode Juni - Agustus 2016 memiliki jumlah individu jantan dan yang betina yang seimbang atau memiliki rasio $1: 1$;

2. Ikan jantan mendominasi TKG I dan TKG IV, sedangkan ikan betina mendominasi TKG II, TKG III. dan TKG V

3. Ikan layang yang tertangkap di perairan Latuhalat sebahagian besarnya merupakan individu dewasa;

4. Ikan layang memiliki pertumbuhan alometrik positif kecuali untuk ikan layang jantan di bulan Agustus yang memiliki pola pertumbuhan isometrik.

\section{Ucapan Terima Kasih}

Penulis mengucapkan terima kasih kepada Juita Enus yang membantu dalam pengumpulan data di lapangan

\section{Daftar Pustaka}

Aprilianty, H., 2000. Aspek Biologi Ikan Layang (Decapterus ruselli) Ruppel di Perairan Teluk Sibolga, Sumatera Utara. Fakultas
Perikanan dan Ilmu Kelautan, Institut Pertanian Bogor. Bogor. 46 hal.

Departemen Kelautan dan Perikanan Provinsi Maluku. 2014. Buku Lumbung Ikan Nasional. Ambon.

Effendie, M. I. 1997. Metode Biologi Perikanan. Bogor : Yayasan Dewi Sri, 162 hal.

Flower, J., Cohen, L. 1992. Practical Statiscics For Field Biology. John Willey \& Sons, 227pp

Genisa, A.S. 1998. Beberapa catatan tentang biologi ikan layang marga Deacpterus. Lembaga IImu Pengetahuan Indonesia. Oseana 23: 27-36.

Manik, N. 2003. Beberapa parameter populasi ikan layang (Decapterus russelli) di Perairan Maluku Utara. Oseanologi dan Limnologi Indonesia 35:65-74.

Manik, N., 2009. Hubungan panjang berat dan faktor kondisi ikan layang (Decapterus russelli) dari perairan sekitar Teluk Likupang, Sulawesi Utara. Oseanologi dan Limnologi di Indonesia 35(1): 65-74.

Pauly, D. 1984. Fish population dynamics in tropical waters: a manual for use with programmable calculators. Iclarm, Manila, 323pp

Prihartini, A., 2006. Analisis Tampilan Biologi Ikan Layang (Decapterus spp.) Hasil Tangkapan Purse Seine yang didaratkan Di PPN Pekalongan. Pogram Pasca Sarjana Universitas Diponegoro. Semarang. 89 hal

Simanjuntak, C.P.H. 2007. Reproduksi ikan selais, Ompok hypopthalmus (Bleeker) berkaitan dengan perubahan hidromorfologi perairan di rawa banjiran Sungai Ampar Kiri. Program Pascasarjana. Institut Pertanian Bogor.

Sparre, P., Venema, S. C. 1992. Introduction to Tropical Fish Stock Assement Part-1 Manual.Marine Resources Service Fishery Resources and Environment Division FAO Fisheries, Dept. Rome Italy, 376pp.

Sulistiono, Soenanthi, K.D., Ernawati, Y. 2009. Aspek reproduksi ikan lidah, Cynoglossus linguna H.B. 1822 di perairan Ujung 
87 Omni-Akuatika Vol. 12 No. 3, 2016 : 79 - 87

Pangkah, Jawa Timur. Jurnal Ikhtiologi Indonesia 9:175-185.

Sumadhiharga, O.K. 1994. Reproduksi dan makanan ikan momar puti (Decapterus macrosoma) di Teluk Ambon. Perairan Maluku dan Sekitarnya 6:27-40.

Turkmen, M., Erdogan, O., Yildirim, A., Akhyurt, I. 2002. Reproductive tactics, age and growth of Capoeta capoeta umla Heckel 1843 from the Askale Region of
theKarasu River, Turkey. Journal Of Fsheries Research 54:317-328.

Widodo, J., 1988. Population dynamics and management of ikan layang, scad mackerel, Decapterus spp (Pisces: Carangidae) in the Java Sea. Ph.D. dissertation, University of Washington, 155pp. 